\title{
Subduction-accretion-collision history along the Gondwana suture in southern India: A laser ablation ICP-MS study of zircon chronology
}

\author{
Kei Sato ${ }^{\mathrm{a}, \mathrm{b}, *}$, M. Santosh ${ }^{\mathrm{c}, \mathrm{d}}$, Toshiaki Tsunogae ${ }^{\mathrm{e}}$, T.R.K. Chetty ${ }^{\mathrm{f}}$, Takafumi Hirata ${ }^{\mathrm{g}}$ \\ a JSPS Research Fellow, Department of Earth and Planetary Sciences, Graduate School of Science and Engineering, Tokyo Institute of Technology, \\ 2-12-1 Ookayama, Tokyo 152-8551, Japan \\ ${ }^{\mathrm{b}}$ Research School of Earth Sciences, The Australian National University, Canberra, ACT 0200, Australia \\ ${ }^{\mathrm{c}}$ Department of Earth and Atmospheric Sciences, Center for Environmental Sciences, Saint Louis University, St. Louis, MO 63108, USA \\ ${ }^{\mathrm{d}}$ Faculty of Science, Kochi University, Akebono-cho 2-5-1, Kochi 780-8520, Japan \\ e Graduate School of Life and Environmental Sciences, University of Tsukuba, Ibaraki 305-8572, Japan \\ ${ }^{\mathrm{f}}$ National Geophysical Research Institute, Uppal Road, Hyderabad 500 007, Andhra Pradesh, India \\ ${ }^{\mathrm{g}}$ Department of Geology and Mineralogy, Graduate School of Science, Kyoto University, Kitashirakawa Oiwakecho, Sakyo-ku, Kyoto 606-8502, Japan
}

\section{A R T I C L E I N F O}

\section{Article history:}

Received 13 November 2009

Received in revised form 21 June 2010

Accepted 24 August 2010

\section{Keywords:}

Gondwana supercontinent

Southern Indian Granulite Terrane

Oceanic plagiogranite

Banded iron formations (BIFs)

Laser ablation ICP mass spectrometry (LA-

ICP-MS)

\begin{abstract}
A B S T R A C T
We report the petrological characteristics and preliminary zircon geochronology based on laser ablation ICP mass spectrometry of the various units in an accretionary belt within the Palghat-Cauvery Shear/ Suture Zone in southern India, a trace of the Cambrian Gondwana suture. Zircons extracted from a plagiogranite in association with an ophiolite suite within this suture possess internal structure that suggests magmatic crystallization, and yield mid Neoproterozoic ${ }^{206} \mathrm{~Pb} /{ }^{238} \mathrm{U}$ age of $817 \pm 16 \mathrm{Ma}$ (error: $1 \sigma$ ) constraining the approximate timing of birth of the Mozambique Ocean floor. Compiled age data on zircons separated from a quartzite and metamorphosed banded iron formation within the accretionary belt yields a younger intercept age of $759 \pm 41 \mathrm{Ma}$ (error: $1 \sigma$ ) which we relate to a mid Neoproteozoic magmatic arc. Detrital zircons extracted from the quartzite yield ${ }^{207} \mathrm{~Pb} /{ }^{206} \mathrm{~Pb}$ age peaks of about $1.9-2.6 \mathrm{Ga}$ suggesting that they were sourced from multiple protolithis of Neoarchean and Paleoproterozoic. Metamorphic overgrowths on some zircon grains record ca. 500-550 Ma ages which are in good harmony with the known ages for the timing of high-grade metamorphism in this zone during the final stage of continent collision associated with the birth of the Gondwana supercontinent in the latest NeoproterozoicCambrian. The preliminary geochronological results documented in our study correlate with the subduction-accretion-collision history associated with the closure of the Mozambique Ocean and the final amalgamation of the Gondwana supercontinent.
\end{abstract}

(c) 2010 Elsevier Ltd. All rights reserved.

\section{Introduction}

The Southern Indian Granulite Terrane occupied a central position in the Gondwana supercontinent assembly in the late Neoproterozoic-Cambrian (Collins and Pisarevsky, 2005; Collins et al., 2007a; Meert and Lieberman, 2008; Santosh et al., 2009a,b; Sato et al., 2010a). Recent studies consider the Palghat-Cauvery Suture Zone (PCSZ) (Fig. 1), which divides the Madurai Block on the south and the Archean Dharwar Craton on the north, as the trace of a suture zone that extended to Madagascar in the west and probably Antarctica in the east within the Gondwana supercontinent ensemble (e.g. Sengupta et al., 1999; Collins et al., 2007a; Santosh et al., 2009b; Raharimahefa and Kusky, 2006, 2009, 2010; Naganjaneyulu and Santosh, 2010). The Madurai Block and the PCSZ

\footnotetext{
* Corresponding author at: Department of Earth and Planetary Sciences, Graduate School of Science and Engineering, Tokyo Institute of Technology, 2-12-1 Ookayama, Tokyo 152-8551, Japan. Tel.: +81 35734 2717; fax: +81 357343538 .

E-mail address: ksato@geo.titech.ac.jp (K. Sato).
}

have figured in several recent studies focusing on the petrology of ultrahigh-temperature (UHT; $T>900{ }^{\circ} \mathrm{C}$ ) metamorphic rocks (e.g. Brown and Raith, 1996; Sajeev et al., 2004; Santosh et al., 2004; Tateishi et al., 2004; Santosh and Sajeev, 2006; Shimpo et al., 2006; Tsunogae et al., 2008a; Sato et al., 2009; Nishimiya et al., 2010; Santosh and Kusky, 2010). The metamorphic processes in this region, including prograde high-pressure metamorphism, peak UHT metamorphism and subsequent isothermal decompression, have been clarified based on careful studies on inclusion minerals, microstructure and mineral chemistry of Al-Mg UHT granulites (Shimpo et al., 2006; Tsunogae et al., 2008a; Sato et al., 2009; Nishimiya et al., 2010), and also confirmed by recent experimental result on the high $P-T$ phase relation on $\mathrm{Mg}_{0.7} \mathrm{Fe}_{0.3}$-staurolite composition in the system $\mathrm{FeO}-\mathrm{MgO}-\mathrm{Al}_{2} \mathrm{O}_{3}-\mathrm{SiO}_{2}-\mathrm{H}_{2} \mathrm{O}$ (Sato et al., 2010b). The UHT metamorphism in the region also witnessed the influx of $\mathrm{CO}_{2}$-rich fluids, as has been suggested by the common presence of highdensity $\mathrm{CO}_{2}$ fluid inclusions trapped during peak metamorphic conditions in various granulite-facies minerals (e.g. Ohyama et al., 2008; Santosh and Omori, 2008; Tsunogae et al., 2008b). The 


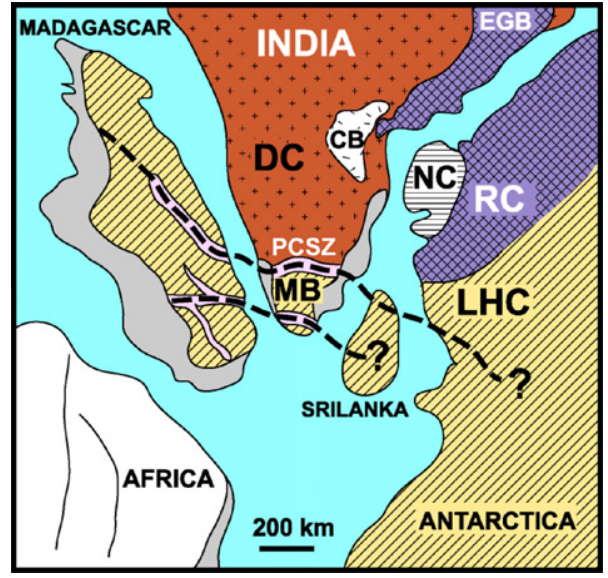

Fig. 1. Illustration showing the central part of Gondwana supercontinent assembly within the Mozambique Ocean suture (after Sengupta et al., 1999; Raharimahefa and Kusky, 2006, 2009; Collins et al., 2007a). Abbreviations for the various complexes: MB, Madurai Block; DC, Archean Dharwar Craton; EGB, Eastern Ghats Belt; CB, Middle Proterozoic Cuddapah sedimentary sequences; NC, Napier Complex; RC, Rayner Complex; LHC, Lützow-Holm Complex; PCSZ, Palghat-Cauvery Shear/Suture Zone.

available geologic, petrologic, geochronologic and experimental data were synthesized in a recent plate tectonic model for southern India which proposed an early Pacific-type accretionary orogeny and a final Himalayan-style collisional orogeny (Santosh et al., 2009b; Santosh and Kusky, 2010).

Most of the published ages from the PCSZ and the Madurai Block have recorded a major thermal event during the late Neoproterozoic-Cambrian at around 540 Ma which can be correlated to the high-grade metamorphism including the formation of UHT rocks associated with the final collisional assembly of the
Gondwana supercontinent (e.g. Santosh et al., 2006; Collins et al., 2007a,b). However, no geochronologic work has been carried out to understand the Neoproterozoic evolution of this collisional margin within a plate tectonic context. The recent discovery of dismembered ophiolite suites in the Manamedu hillock within the PCSZ and surrounding regions (Santosh et al., 2009b, 2010; Yellappa et al., 2010) provides opportunities for detailed studies on Ocean Plate Stratigraphy (e.g. Isozaki, 1997) and on subduction-accretion tectonics prior to the final collision. In this study, we investigate a suite of rock samples from critical localities within and around the PCSZ and present results from a preliminary $\mathrm{U}-\mathrm{Pb}$ zircon geochronology using laser ablation ICP mass spectrometry (LA-ICP-MS) technique on zircon grains from a plagiogranite associated with an ophiolite suite, and metamorphosed banded iron formation (BIF) and quartzite from another locality within the accretionary belt to evaluate the Neoproterozoic subduction-accretion-collision history in this region during the birth of Gondwana supercontinent.

\section{Geological background}

Southern India comprises two contrasting tectonic provinces with the Archean Dharwar Craton in the north and a collage of the Proterozoic granulite-facies blocks in the south (Figs. 1 and 2), dissected by the Palghat-Cauvery and the Achankovil Shear/Suture Zones. Previous studies considered a polymetamorphic history for the granulite-facies blocks that were built during a long-span of time in the Earth history from early Archean to late Neoproterozoic (e.g. Harris et al., 1994; Bartlett et al., 1998). However, recent petrologic and geochronologic data have confirmed that the Proterozoic mosaic in the south witnessed a major Cambrian metamorphic tectonothermal event associated with the final stage of collisional amalgamation of the Gondwana supercontinent (e.g. Santosh

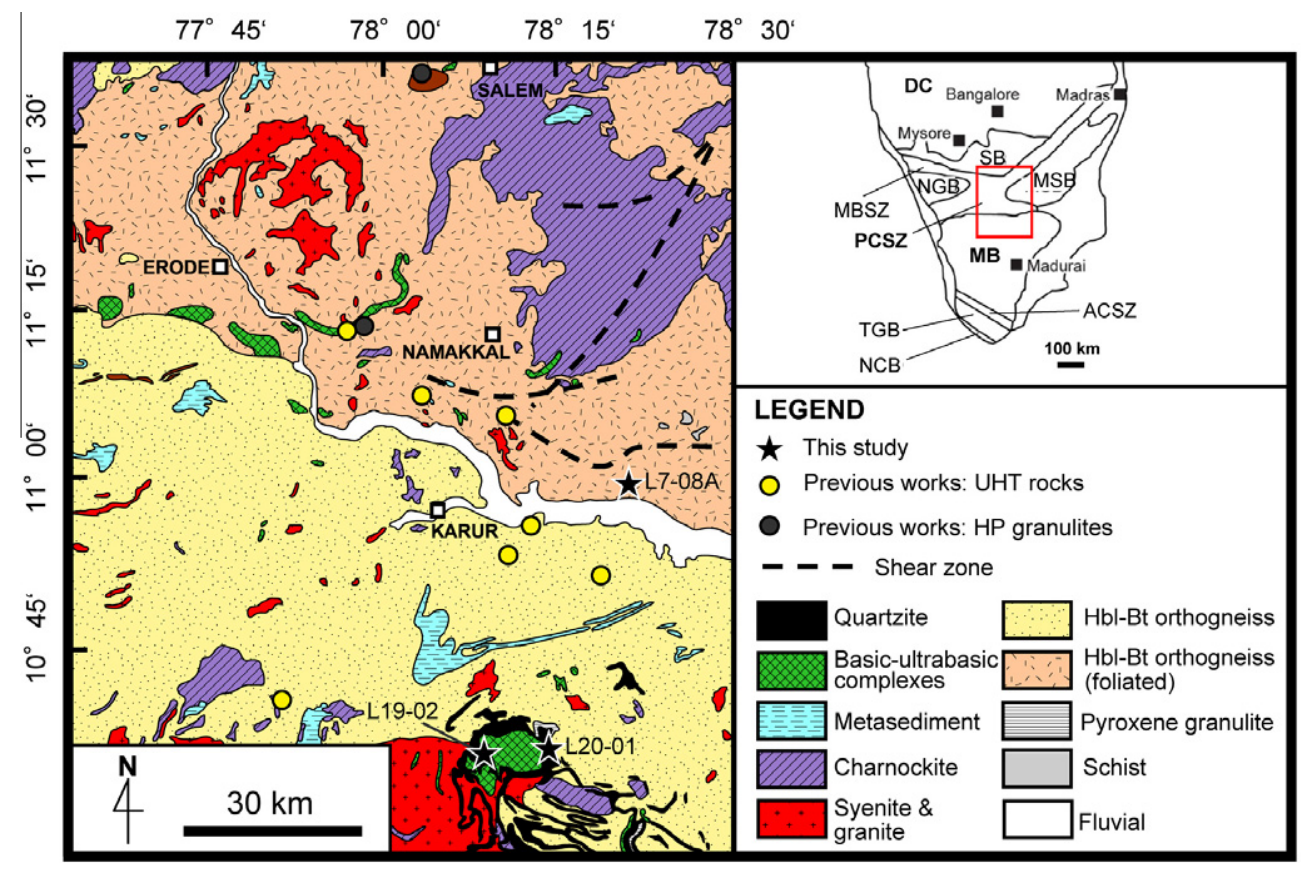

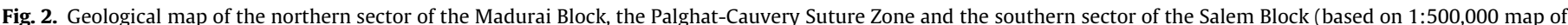

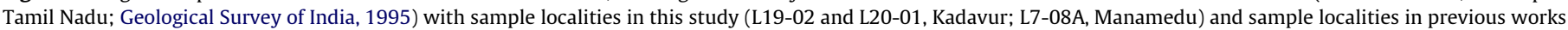

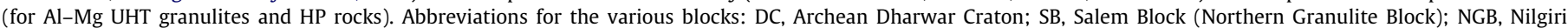

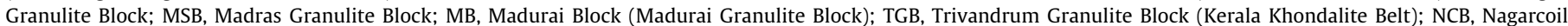

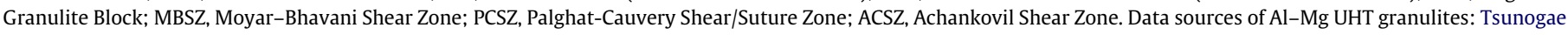

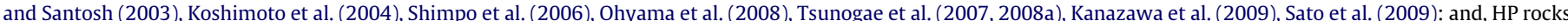

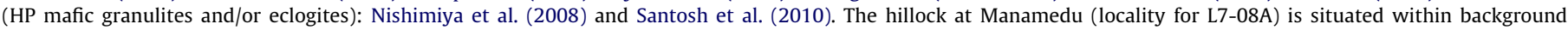
lithology, orthogneiss (Yellappa et al., 2010). 
et al., 2006; Collins et al., 2007a,b). These studies also identified the PCSZ as the trace of the suture that was developed by the closure of the Mozambique Ocean in the latest Neoproterozoic.

To the north of the PCSZ is the Salem Block, which was previously referred as the Northern Granulite Terrane (e.g. Chetty and Bhaskar Rao, 2006a,b), charnockites (hypersthene-bearing felsic granulites) yielded SHRIMP U-Pb zircon ages of ca. $2530 \mathrm{Ma}$ for the magmatic protolith and ca. $2480 \mathrm{Ma}$ for the high-grade metamorphism (Clark et al., 2009). A metamorphic age of ca. $2440 \mathrm{Ma}$ for metamorphosed granite of the southernmost part of the Salem Block was also reported based on LA-ICP-MS U-Pb zircon dating (Sato et al., in press). On the other hand, the crustal fragments including the Madurai, Trivandrum and Nagercoil Granulite Blocks to the south of the PCSZ preserve the common imprint of a major thermal event during the latest Neoproterozoic-Cambrian (e.g. Miller et al., 1996; Bartlett et al., 1998; Bhaskar Rao et al., 2003; Santosh et al., 2003, 2006; Collins et al., 2007a,b), with all of the rocks subjected to granulite-facies and/or UHT metamorphism (e.g. Brown and Raith, 1996; Koshimoto et al., 2004; Morimoto et al., 2004; Tateishi et al., 2004; Ishii et al., 2006; Tadokoro et al., 2007, 2008; Sato et al., 2009; Tsunogae and Santosh, 2010). Ages older than $3000 \mathrm{Ma}$ have also been reported from the Madurai Block in some studies and considered as probable protolith ages (Miller et al., 1996; Bartlett et al., 1998; Bhaskar Rao et al., 2003).

Within the PCSZ, regional structural studies have identified a transpressional tectonic regime and a prominent crustal flower structure which were correlated to extrusion tectonics (Chetty and Bhaskar Rao, 2006a). Most of the recent petrological studies in this region focus on $\mathrm{Al}-\mathrm{Mg}$ UHT granulites and high-pressure (HP) granulites concentrated within an area of 30-40 km surrounding the Karur town in the Tamil Nadu State (Fig. 2) (e.g. Koshimoto et al., 2004; Shimpo et al., 2006; Santosh et al., 2004; Tsunogae et al., 2007, 2008a; Nishimiya et al., 2008, 2010; Ohyama et al., 2008; Kanazawa et al., 2009; Sato et al., 2009; Tsunogae and Santosh, 2010). For example, metamorphic $P-T$ trajectories including prograde high-pressure metamorphism, peak UHT metamorphism, and subsequent isothermal decompression for the PCSZ system were confirmed from $\mathrm{Al}-\mathrm{Mg}$ granulites with moderate$\mathrm{Mg}\left(\mathrm{Fe}_{0.5} \mathrm{Mg}_{0.5}\right)$ staurolite inclusions in poikiloblastic garnets (Shimpo et al., 2006; Tsunogae and Santosh, 2006; Tsunogae et al., 2008a; Sato et al., 2009; Nishimiya et al., 2010) and also from an experimental study on the magnesian $\left(\mathrm{Fe}_{0.7} \mathrm{Mg}_{0.3}\right)$ staurolite composition in the system $\mathrm{FeO}-\mathrm{MgO}-\mathrm{Al}_{2} \mathrm{O}_{3}-\mathrm{SiO}_{2}-\mathrm{H}_{2} \mathrm{O}$ (Sato et al., 2010b). On the other hand, the rock types in the northern part of the PCSZ system and the southern part of the Salem Block are characterized by the occurrence of retrogressed HP granulites (Nishimiya et al., 2008; Santosh et al., 2010). Whereas these studies contributed significantly to the understanding of extreme metamorphism in a collisional orogen, no detailed studies have so far been attempted to investigate the various other rock types in elucidating the regional tectonic scenario and the accretionary growth within this suture. In this study, we performed $\mathrm{U}-\mathrm{Pb}$ age dating of zircon grains from a plagiogranite, metamorphosed banded iron formation (BIF) and quartzite from different localities within the accretionary belt of the PCSZ and northern segment of the Madurai Block. The geological features and structural characteristics of these localities suggesting imbricated ocean floor stratigraphy in an accretionary complex of these localities are documented in detail in our recent works (e.g. Santosh et al., 2009b; Yellappa et al., 2010; T.R.K. Chetty et al., unpublished data).

\section{Analytical procedures}

The zircon grains were extracted at Tokyo Institute of Technology following the technique described in Katayama et al. (2001).
Representative fresh rock samples were crushed and sieved followed by magnetic and heavy liquid separations. The extracted zircon grains were mounted on epoxy disc, and were polished. The zircons were identified by a laser Raman spectrophotometer (NRS-2000C, JASCO) with the $514.5 \mathrm{~nm}$ line of an Ar-ion laser at the Tokyo Inst. Tech. Internal structures of the zircons were examined optically, and also by cathode luminescence (CL) images.

The LA-ICP-MS spot-analyses for the U-Pb zircon dating were performed by a ThermoFisher VG PlasmaQuad $\Omega$ quadrupole based ICP-mass spectrometer equipped with the S-option interface (Hirata and Nesbitt, 1995). For the laser ablation analyses, a MicroLas production (Göttingen, Germany) GeoLas 200CQ laser ablation system with Lambda Physik (Göttingen, Germany) COMPex 102 ArF excimer laser as a $193 \mathrm{~nm}$ DUV (deep ultraviolet) light source was used. To improve the sample transport efficiency from the sample cell to the ICP, and to reduce sample depositing around the ablation pit, He gas was used for flushing the ablation site (Eggins et al., 1998). Operational settings for ICP conditions and lens biases were optimized to maximize the signal intensity of the ${ }^{208} \mathrm{~Pb}$ signal obtained by laser ablation of NIST SRM 610. Ion sampling depth (torch position) and ion energy was carefully optimized to maximize the signal intensity and to minimize the background count at $208 \mathrm{Da}$. All measurements were performed with peak jump acquisition mode at the peaks of ${ }^{139} \mathrm{La},{ }^{202} \mathrm{Hg},{ }^{204} \mathrm{~Pb}\left({ }^{204} \mathrm{Hg}\right),{ }^{206} \mathrm{~Pb},{ }^{207} \mathrm{~Pb}$, ${ }^{232} \mathrm{Th}$ and ${ }^{238} \mathrm{U}$. A major problem associated with the analysis of ${ }^{204} \mathrm{~Pb}$ using the LA-ICP-MS is ${ }^{204} \mathrm{Hg}$ isobaric interference, because the $\mathrm{Hg}$ signals do not decay with time and the ${ }^{204} \mathrm{Hg}$ mainly originates from Ar gas. The ${ }^{204} \mathrm{Hg}$ was corrected by measuring ${ }^{202} \mathrm{Hg}$. In order to reduce the isobaric interference of ${ }^{204} \mathrm{Hg}$, a Hg-trap device using an activated charcoal filter was applied to the Ar makeup gas before mixing with the He carrier gas (Hirata et al., 2005). Standardization for the calibration of $\mathrm{Pb} / \mathrm{U}$ ratio utilizing Nancy 91500 zircon was performed as follows: ${ }^{206} \mathrm{~Pb} /{ }^{238} \mathrm{U}=0.1792$ (Wiedenbeck et al., 1995), ${ }^{238} \mathrm{U} /{ }^{235} \mathrm{U}=137.88 .{ }^{207} \mathrm{~Pb} /{ }^{206} \mathrm{~Pb}$ ratio (=0.9096; Walder et al., 1993) was calibrated against NIST SRM 610 (Iizuka and Hirata, 2004). Each spot analysis was set as follows: LAM power: $140 \mathrm{~mJ} /$ pulse; spot size: $16 \mu \mathrm{m}$; repetition rate: $7 \mathrm{~Hz}$; measurement duration: $7 \mathrm{~s}$. The analytical results of $\mathrm{U}-\mathrm{Pb}$ age dating (with consideration for common Pb correction; Stacey and Kramers, 1975) for 30 spots on 22 zircon grains are presented in Table 1 . The concordia diagram for the $\mathrm{Pb} / \mathrm{U}$ ratios in each sample was drawn using the Isoplot/Ex 3.00 Beta program supplied by Berkeley Geochronology Center (Ludwig, 2003).

To characterize the mineral assemblages and textural features, all rocks were studied under thin section before the LA-ICP-MS analyses. Representative minerals were analyzed for their major element composition (Table 2) using an electron probe micro analyser (EPMA; JXA8800, JEOL). The analyses were conducted under conditions of $15 \mathrm{kV}$ accelerating voltage and $1.20 \times 10^{-8}$ A current, and the data were regressed using an oxide-ZAF correction program supplied by JEOL. Counting time in the EPMA studies was set as $20 \mathrm{~s}$ for each spot and $10 \mathrm{~s}$ for background measurements of peak on the each spot. On the basis of size of contamination spots that formed by chemical analyses, beam diameter was estimated as $1-2 \mu \mathrm{m}$.

\section{Field relationship and petrology}

\subsection{Quartzite and metamorphosed BIFs (Kadavur)}

The Kadavur region is situated in the northernmost part of the Madurai Block, about $50 \mathrm{~km}$ south-southeast of the Karur town in the Tamil Nadu State (Fig. 2). Here, several tens of meters thick quartzite bands are widely distributed covering an area of $40 \times 40 \mathrm{~km}^{2}$ which crops out as prominent ridges running over 
Table 1

LA-ICP-MS analytical results.

\begin{tabular}{|c|c|c|c|c|c|c|c|c|c|c|c|c|c|c|}
\hline \multirow{2}{*}{$\begin{array}{l}\text { Sample } \\
\text { No. }\end{array}$} & \multirow[t]{2}{*}{ Locality } & \multirow{2}{*}{$\begin{array}{l}\text { Spot } \\
\text { No. }\end{array}$} & \multicolumn{6}{|c|}{ Calculated ratios } & \multicolumn{6}{|l|}{ Ages (Ma) } \\
\hline & & & ${ }^{207} \mathrm{~Pb} /{ }^{235} \mathrm{U}$ & $\pm(1 \sigma)$ & ${ }^{206} \mathrm{~Pb} /{ }^{238} \mathrm{U}$ & $\pm(1 \sigma)$ & ${ }^{207} \mathrm{~Pb} /{ }^{206} \mathrm{~Pb}$ & $\pm(1 \sigma)$ & ${ }^{207} \mathrm{~Pb} /{ }^{235} \mathrm{U}$ & $\pm(1 \sigma)$ & ${ }^{206} \mathrm{~Pb} /{ }^{238} \mathrm{U}$ & $\pm(1 \sigma)$ & ${ }^{207} \mathrm{~Pb} /{ }^{206} \mathrm{~Pb}$ & $\pm(1 \sigma)$ \\
\hline \multirow{8}{*}{$\begin{array}{c}\text { KS081228- } \\
\text { L19-02 }\end{array}$} & \multirow[t]{8}{*}{ Kadavur } & 1 & 1.1330 & 0.0521 & 0.1196 & 0.0047 & 0.0687 & 0.0005 & 769.2 & 24.8 & 728.3 & 26.9 & 889.8 & 15.6 \\
\hline & & 2 & 1.1477 & 0.0528 & 0.1192 & 0.0047 & 0.0698 & 0.0005 & 776.2 & 25.0 & 725.8 & 26.8 & 923.8 & 15.5 \\
\hline & & 3 & 1.2192 & 0.0560 & 0.1225 & 0.0048 & 0.0722 & 0.0005 & 809.4 & 25.7 & 744.7 & 27.5 & 991.8 & 15.3 \\
\hline & & 4 & 1.2985 & 0.0597 & 0.1350 & 0.0053 & 0.0698 & 0.0005 & 845.0 & 26.4 & 816.2 & 29.9 & 921.7 & 15.5 \\
\hline & & 5 & 1.1946 & 0.0549 & 0.1238 & 0.0048 & 0.0700 & 0.0005 & 798.1 & 25.4 & 752.4 & 27.7 & 927.9 & 15.5 \\
\hline & & 6 & 1.2522 & 0.0576 & 0.1309 & 0.0051 & 0.0694 & 0.0005 & 824.4 & 26.0 & 793.0 & 29.1 & 910.0 & 15.5 \\
\hline & & 7 & 1.1305 & 0.0520 & 0.1281 & 0.0050 & 0.0640 & 0.0005 & 768.0 & 24.8 & 776.8 & 28.6 & 742.3 & 16.0 \\
\hline & & 8 & 0.6397 & 0.0294 & 0.0800 & 0.0031 & 0.0580 & 0.0004 & 502.1 & 18.2 & 496.4 & 18.7 & 528.3 & 16.5 \\
\hline \multirow{18}{*}{$\begin{array}{c}\text { KS081228- } \\
\text { L20-01 }\end{array}$} & \multirow[t]{18}{*}{ Kadavur } & 9 & 9.9141 & 0.7072 & 0.4780 & 0.0258 & 0.1504 & 0.0028 & 2426.8 & 66.2 & 2518.4 & 112.7 & 2350.8 & 30.8 \\
\hline & & 10 & 11.0549 & 0.7886 & 0.4580 & 0.0247 & 0.1751 & 0.0032 & 2527.8 & 66.8 & 2430.8 & 109.4 & 2606.5 & 30.0 \\
\hline & & 11 & 10.6225 & 0.7577 & 0.4760 & 0.0257 & 0.1619 & 0.0030 & 2490.7 & 66.6 & 2509.6 & 112.4 & 2475.2 & 30.3 \\
\hline & & 12 & 3.0912 & 0.2205 & 0.2564 & 0.0139 & 0.0874 & 0.0016 & 1430.5 & 54.9 & 1471.5 & 71.1 & 1370.1 & 34.5 \\
\hline & & 13 & 6.2862 & 0.4484 & 0.3635 & 0.0196 & 0.1254 & 0.0023 & 2016.5 & 62.8 & 1998.9 & 92.9 & 2034.6 & 31.8 \\
\hline & & 14 & 6.3408 & 0.4523 & 0.3847 & 0.0208 & 0.1195 & 0.0022 & 2024.1 & 62.9 & 2098.3 & 96.8 & 1949.2 & 32.1 \\
\hline & & 15 & 7.1679 & 0.5113 & 0.3853 & 0.0208 & 0.1349 & 0.0025 & 2132.5 & 63.9 & 2101.1 & 96.9 & 2162.9 & 31.3 \\
\hline & & 16 & 9.0626 & 0.6464 & 0.4343 & 0.0235 & 0.1514 & 0.0028 & 2344.3 & 65.6 & 2324.9 & 105.5 & 2361.3 & 30.6 \\
\hline & & 17 & 7.9465 & 0.3781 & 0.4399 & 0.0136 & 0.1310 & 0.0023 & 2225.0 & 43.0 & 2350.2 & 60.9 & 2111.5 & 29.8 \\
\hline & & 18 & 8.9338 & 0.4251 & 0.4415 & 0.0136 & 0.1468 & 0.0026 & 2331.3 & 43.6 & 2357.3 & 61.0 & 2308.5 & 29.3 \\
\hline & & 19 & 10.2093 & 0.4857 & 0.4890 & 0.0151 & 0.1514 & 0.0026 & 2453.9 & 44.1 & 2566.4 & 65.4 & 2362.0 & 29.1 \\
\hline & & 20 & 5.4589 & 0.2597 & 0.3486 & 0.0108 & 0.1136 & 0.0020 & 1894.2 & 40.9 & 1927.8 & 51.5 & 1857.5 & 30.8 \\
\hline & & 21 & 10.3554 & 0.4927 & 0.5044 & 0.0156 & 0.1489 & 0.0026 & 2467.1 & 44.2 & 2632.8 & 66.8 & 2333.2 & 29.2 \\
\hline & & 22 & 17.3532 & 0.8258 & 0.5951 & 0.0184 & 0.2115 & 0.0037 & 2954.6 & 45.8 & 3010.0 & 74.3 & 2917.0 & 27.6 \\
\hline & & 23 & 5.2357 & 0.3124 & 0.3260 & 0.0173 & 0.1165 & 0.0009 & 1858.5 & 51.0 & 1818.8 & 84.2 & 1903.1 & 13.2 \\
\hline & & 24 & 7.5260 & 0.4490 & 0.4061 & 0.0216 & 0.1344 & 0.0010 & 2176.1 & 53.7 & 2197.1 & 98.9 & 2156.3 & 12.8 \\
\hline & & 25 & 9.6254 & 0.5742 & 0.4396 & 0.0233 & 0.1588 & 0.0012 & 2399.6 & 55.1 & 2348.9 & 104.6 & 2442.8 & 12.5 \\
\hline & & 26 & 1.4504 & 0.0865 & 0.1511 & 0.0080 & 0.0696 & 0.0005 & 910.0 & 35.9 & 907.2 & 45.0 & 916.8 & 15.2 \\
\hline \multirow{4}{*}{$\begin{array}{c}\text { KS081225- } \\
\text { L7-08A }\end{array}$} & \multirow[t]{4}{*}{ Manamedu } & 27 & 1.2205 & 0.0399 & 0.1359 & 0.0034 & 0.0651 & 0.0005 & 810.0 & 18.2 & 821.6 & 19.2 & 778.3 & 14.9 \\
\hline & & 28 & 1.1273 & 0.0673 & 0.1311 & 0.0070 & 0.0624 & 0.0005 & 766.5 & 32.2 & 794.1 & 39.7 & 686.7 & 15.7 \\
\hline & & 29 & 1.1995 & 0.0716 & 0.1357 & 0.0072 & 0.0641 & 0.0005 & 800.3 & 33.1 & 820.1 & 40.9 & 745.8 & 15.6 \\
\hline & & $30^{\mathrm{a}}$ & 0.6496 & 0.0397 & 0.0889 & 0.0047 & 0.0530 & 0.0004 & 508.2 & 24.5 & 548.9 & 27.9 & 329.0 & 16.8 \\
\hline
\end{tabular}

a ${ }^{207} \mathrm{~Pb}$ was not collected efficiently, but ${ }^{206} \mathrm{~Pb}$ was detected independently of the collection of ${ }^{207} \mathrm{~Pb}$ (spot No. 30).

Table 2

EPMA analytical results.

\begin{tabular}{|c|c|c|c|c|c|c|c|}
\hline \multirow{2}{*}{$\begin{array}{l}\text { Sample No. } \\
\text { Rock type } \\
\text { Phase }\end{array}$} & \multicolumn{3}{|c|}{$\begin{array}{l}\text { KS081225-L7-08A } \\
\text { Plagiogranite from Manamedu }\end{array}$} & \multicolumn{4}{|c|}{$\begin{array}{l}\text { KS081228-L19-02 } \\
\text { Metamorphosed BIF from Kadavur }\end{array}$} \\
\hline & Qtz & $\mathrm{Pl}$ & $\pm \mathrm{Bt}$ & Opx & Si-rich phase & Hem & il \\
\hline $\mathrm{SiO}_{2}$ & 99.71 & 64.60 & 45.56 & 54.06 & 89.59 & 0.61 & 0.01 \\
\hline $\mathrm{TiO}_{2}$ & 0.04 & 0.02 & 0.82 & 0.06 & n.d. & 0.11 & 49.28 \\
\hline $\mathrm{Al}_{2} \mathrm{O}_{3}$ & 0.00 & 22.63 & 32.48 & 1.54 & 0.90 & 0.40 & 0.04 \\
\hline $\mathrm{Cr}_{2} \mathrm{O}_{3}$ & 0.00 & 0.01 & 0.00 & 0.00 & n.d. & 0.74 & 0.04 \\
\hline $\mathrm{FeO}$ & 0.01 & 0.03 & 4.51 & 22.54 & 0.69 & 85.21 & 47.23 \\
\hline $\mathrm{MnO}$ & 0.01 & 0.01 & 0.04 & 0.12 & n.d. & n.d. & 0.11 \\
\hline $\mathrm{MgO}$ & 0.00 & 0.00 & 2.69 & 22.34 & 0.04 & 0.10 & 1.48 \\
\hline $\mathrm{NiO}$ & 0.01 & 0.01 & 0.08 & 0.01 & 0.01 & n.d. & 0.01 \\
\hline $\mathrm{CaO}$ & 0.00 & 3.79 & 0.02 & 0.74 & 0.05 & n.d. & n.d. \\
\hline $\mathrm{Na}_{2} \mathrm{O}$ & 0.00 & 8.31 & 0.28 & 0.02 & 0.02 & n.d. & 0.02 \\
\hline $\mathrm{K}_{2} \mathrm{O}$ & 0.00 & 0.42 & 9.85 & 0.01 & 0.04 & n.d. & n.d. \\
\hline Total & 99.78 & 99.83 & 96.32 & 101.44 & 91.34 & 87.16 & 98.20 \\
\hline Oxygen & 2 & 8 & 22 & 6 & 2 & 6 & 6 \\
\hline $\mathrm{Si}$ & 1.000 & 2.845 & 6.103 & 1.983 & 0.987 & 0.033 & 0.000 \\
\hline $\mathrm{Ti}$ & 0.000 & 0.001 & 0.083 & 0.002 & n.d. & 0.005 & 1.878 \\
\hline $\mathrm{Al}$ & 0.000 & 1.174 & 5.128 & 0.066 & 0.012 & 0.026 & 0.002 \\
\hline $\mathrm{Cr}$ & 0.000 & 0.000 & 0.000 & 0.000 & n.d. & 0.032 & 0.002 \\
\hline $\mathrm{Fe}^{3+}$ & & & & 0.000 & & 3.867 & 0.242 \\
\hline $\mathrm{Fe}^{2+}$ & 0.000 & 0.001 & 0.505 & 0.692 & 0.006 & 0.030 & 1.759 \\
\hline $\mathrm{Mn}$ & 0.000 & 0.000 & 0.004 & 0.004 & n.d. & n.d. & 0.005 \\
\hline $\mathrm{Mg}$ & 0.000 & 0.000 & 0.537 & 1.222 & 0.001 & 0.008 & 0.111 \\
\hline $\mathrm{Ni}$ & 0.000 & 0.000 & 0.008 & 0.000 & 0.000 & n.d. & 0.000 \\
\hline $\mathrm{Ca}$ & 0.000 & 0.179 & 0.003 & 0.029 & 0.001 & n.d. & n.d. \\
\hline $\mathrm{Na}$ & 0.000 & 0.709 & 0.073 & 0.001 & 0.000 & n.d. & 0.001 \\
\hline K & 0.000 & 0.023 & 1.683 & 0.000 & 0.001 & n.d. & n.d. \\
\hline Total cation & 1.000 & 4.934 & 14.128 & 4.000 & 1.007 & 4.000 & 4.000 \\
\hline $\mathrm{Mg} /(\mathrm{Fe}+\mathrm{Mg})$ & & & 0.515 & & & & \\
\hline $\mathrm{Mg} /\left(\mathrm{Fe}^{2+}+\mathrm{Mg}\right)$ & & & & 0.639 & & & 0.060 \\
\hline
\end{tabular}

Note: Abbreviations for minerals are after Kretz (1983). 
several kilometers (Fig. 2). One of the quartzite ridges which defines a large folded band extending over ten $\mathrm{km}$ around Kadavur was selected for this study. The quartzite used for the age dating (sample: KS081228-L20-01) was collected from a tight ring-like fold in the quartzite band (Fig. 3a and b). The rock consists dominantly of quartz grains in a granular mosaic, and carries abundant zircons as accessory. The widespread quartzite ridges are regarded as metamorphosed arkosic sediments in a passive margin which were subducted and accreted onto the northern margin of the Madurai Block during the final collision stage. Large (few meters to several tens of meters) bands, blocks and fragments of laminated and metamorphosed BIFs occur together with the quartzites of Kadavur. The metamorphosed BIF (sample: KS081228-L19-02; Fig. 4a and b) is composed of ilmenite and iron oxides (mostly hematite) with characteristics presence of orthopyroxene. The orthopyroxene from the BIF shows $\mathrm{Mg \#}[=\mathrm{Mg} /(\mathrm{Fe}+\mathrm{Mg})]$ of 0.64 and $\mathrm{Al}$ content of $1.54 \mathrm{wt} . \%$ (Table 2).

\subsection{Plagiogranite (Manamedu)}

The plagiogranite examined in this study comes from the hillock at Manamedu, about $35 \mathrm{~km}$ east of Karur (Fig. 2) and belongs to a probable ophiolite suite described in Santosh et al. (2009b). Recently Yellappa et al. (2010) reported the detailed petrological
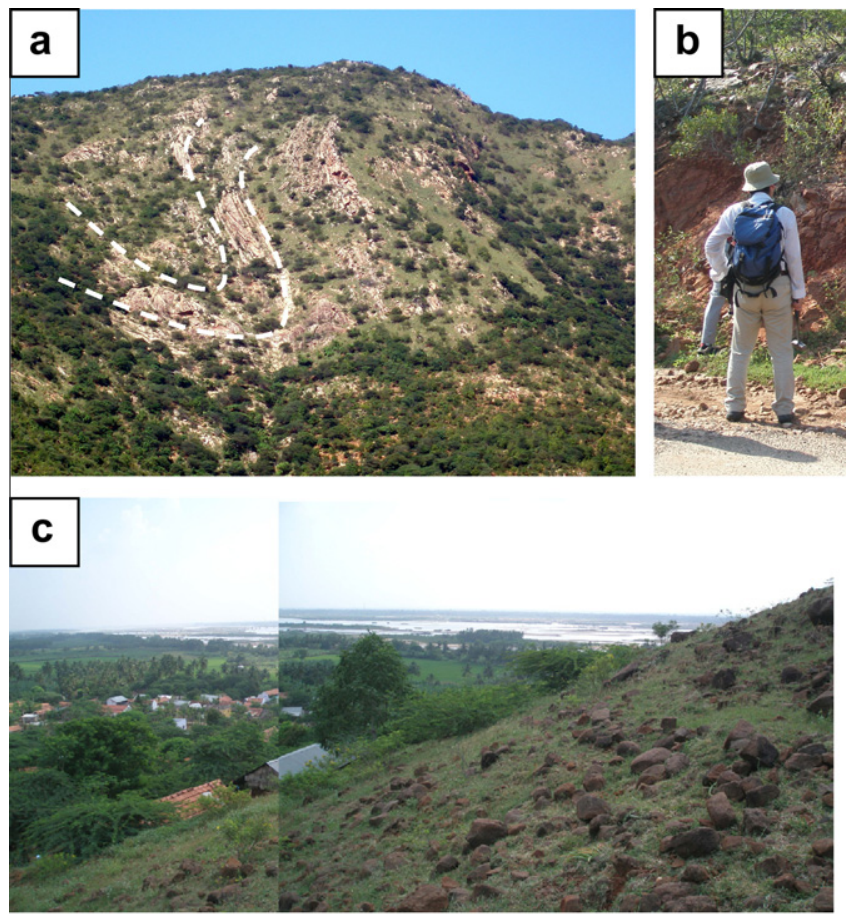
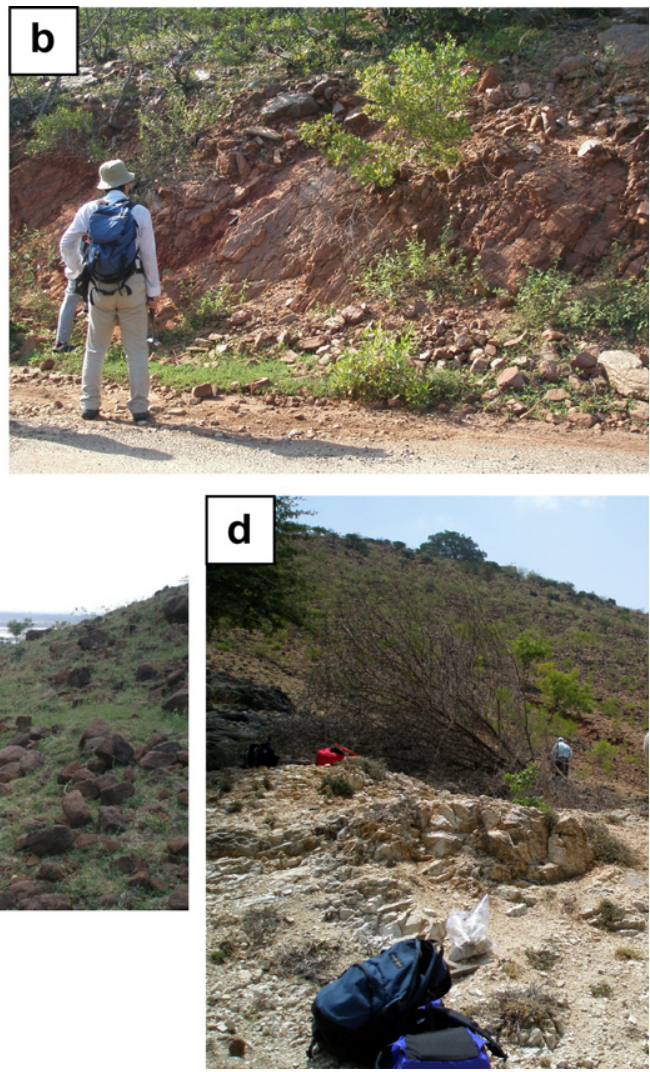

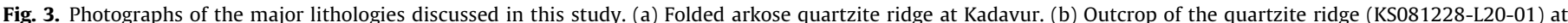
Kadavur. (c) Thick succession of gabbro at Manamedu. (d) Pool or vein of plagiogranite (KS081225-L7-08A) at Manamedu.
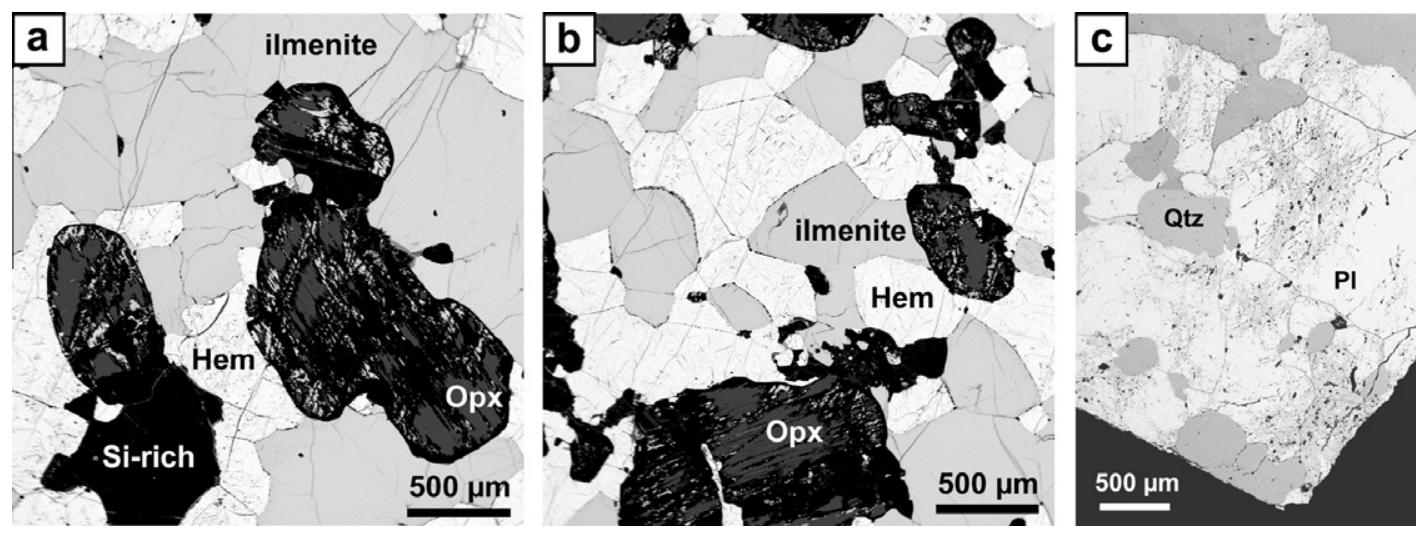

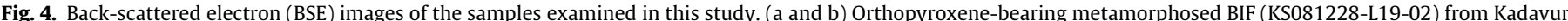

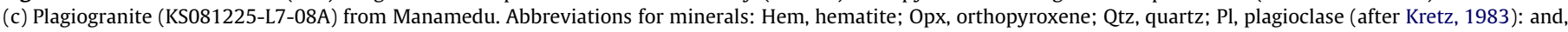
$\mathrm{Si}$-rich, $\mathrm{SiO}_{2}$ rich phase (see Table 2). 
and geochemical characteristics of the various lithologic units associated with this ophiolite suite and based on petrogenetic modeling, they suggested that the suite corresponds to a supra-subduction zone ophiolite assemblage. Detailed structural analysis of the Manamedu complex has revealed classic duplex structures and other features typical of an accretionary complex (T.R.K. Chetty et al., unpublished data). At Manamedu, a ca. $100 \mathrm{~m}$ high rocky hill extending over $500 \mathrm{~m}$ exposes a thick succession of gabbro in association with pools and veins of plagiogranites (Fig. 3c and d). Metamorphosed basaltic rocks, thin layers of cumulate pyroxenite and a thick horizon of isotropic gabbro zone (up to $40 \mathrm{~m}$ ) intruded by multiple mafic dykes (displaying back veining similar to sheeted dykes in other ophiolite complexes) characterize the Manamedu complex. The plagiogranite layer occurs at the stratigraphically base of the sequence, and also forms thin veins and pools that invade the other rock units. Petrological studies and geochemical investigations (Hussain et al., 1996; Yellappa et al., 2010) have clearly identified these felsic units as plagiogranites. Santosh et al. (2009b) suggested that the Manamedu complex probably represents a thrust slice of the ocean floor and may provide potential evidence for an ophiolite suite associated with the suturing of Gondwana supercontinent.

The plagiogranite analyzed in this study (sample: KS081225-L708A; Fig. 4c) is medium to fine grained and dominantly composed of quartz and Na-rich plagioclase (Table 2). Trace of biotite occurs as accessory. Characteristically, zircon grains are extremely rare in plagiogranite and are small in size, due to the low zirconium content in oceanic crust.

\section{Zircon chronology}

\subsection{Quartzite and metamorphosed BIF (Kadavur)}

$\mathrm{CL}$ images of zircon grains extracted from the quartzite (KS081228-L20-01) and the metamorphosed BIF (KS081228-L19-02) from Kadavur are shown in Fig. 5. Detrital zircons are commonly

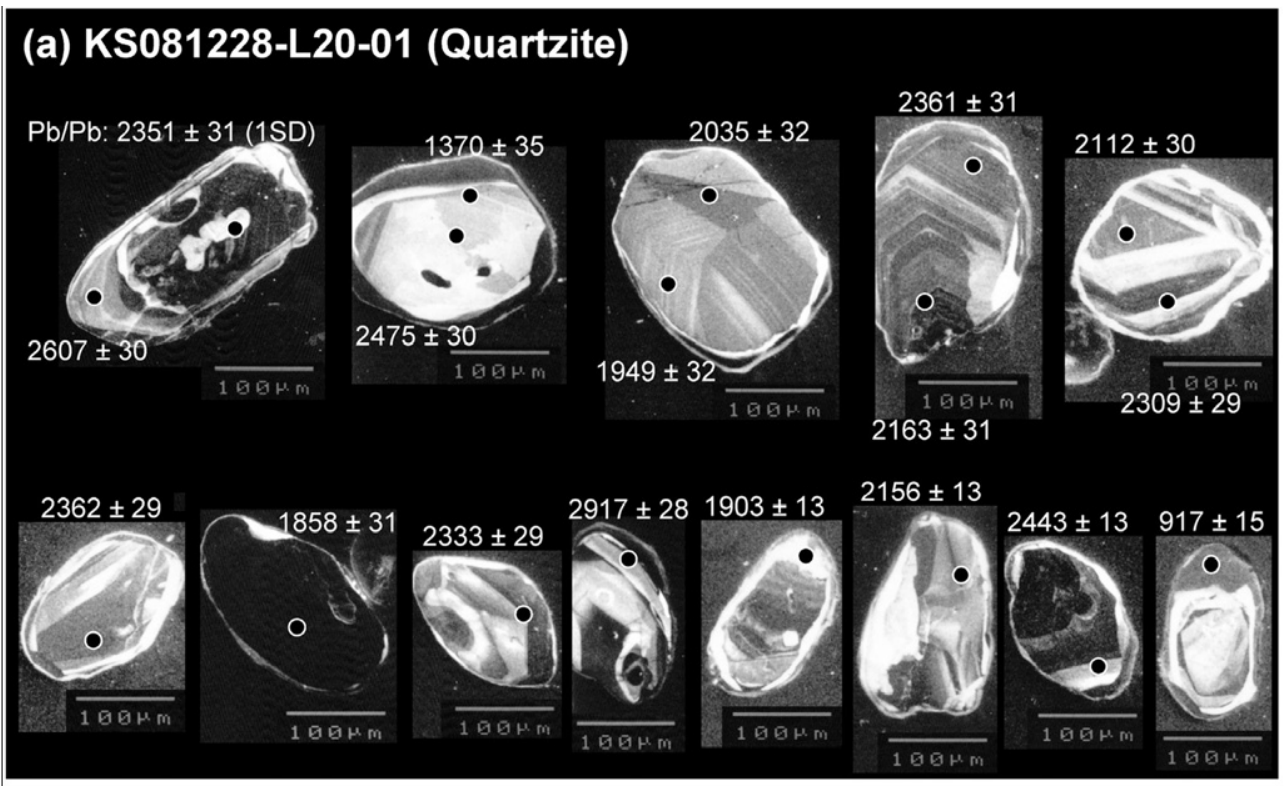

\section{(b) KS081228-L19-02 (Opx-brg. Meta-BIF)}

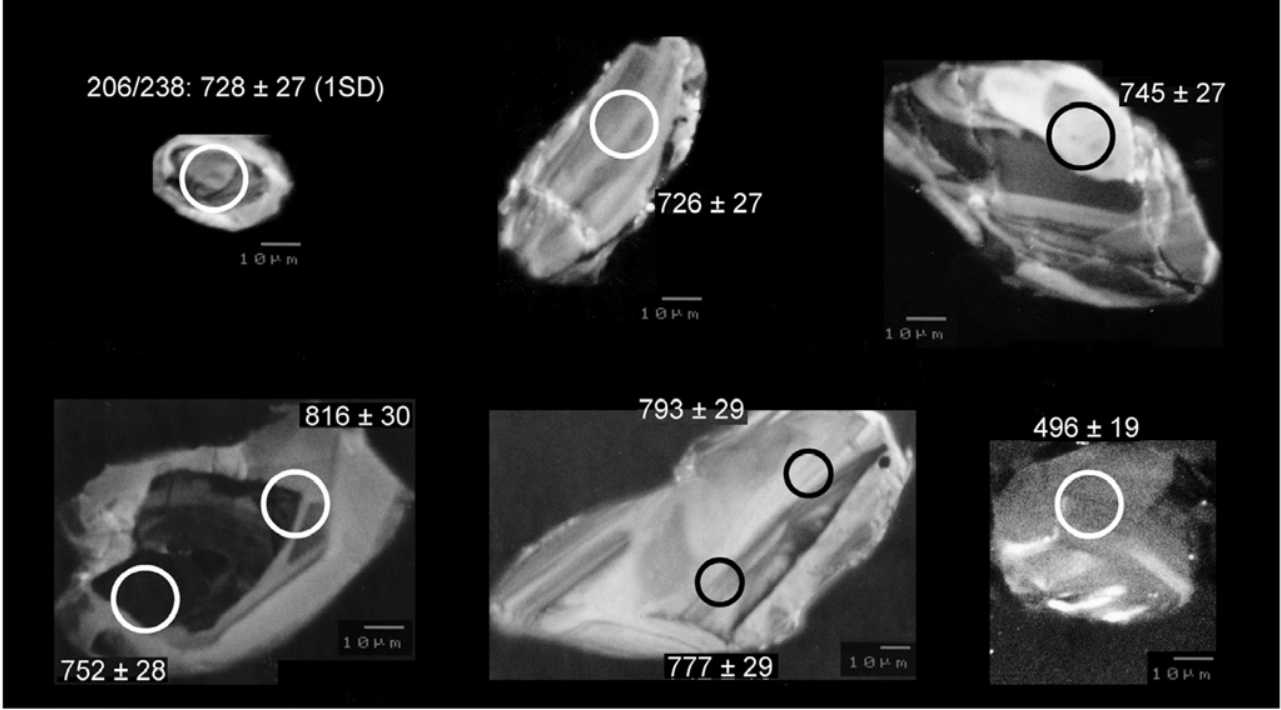

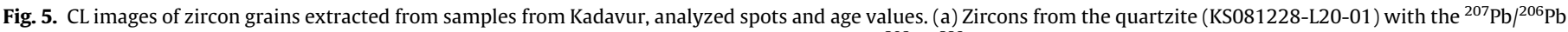
ages. (b) Zircons from orthopyroxene-bearing metamorphosed BIF (KS081228-L19-02) with the ${ }^{206} \mathrm{~Pb} /{ }^{238} \mathrm{U}$ ages. Spot size of each laser ablation: $16 \mu \mathrm{m}$. 
present in the quartzite, and the grains are relatively large (up to $200 \mu \mathrm{m}$ along a long axis; Fig. 5a). Most of the zircons are subhedral to anhedral. The majority of grains display typical internal growth patterns suggesting derivation from magmatic protoliths, and some of the grains carry thin rims of metamorphic overgrowth. The concordia diagram with age data frequency shows prominent ${ }^{207} \mathrm{~Pb} /{ }^{206} \mathrm{~Pb}$ age peaks of about $1900-2600 \mathrm{Ma}$ (Fig. 6) suggesting that the zircons were sourced from Neoarchean and Paleoproterozoic sources.

Zircons are not common in non-metamorphosed BIF samples. From the orthopyroxene-bearing metamorphosed BIF examined in this study (KS081228-L19-02), we could recover only six zircon grains (Fig. 5b). Some zircons display typical internal structure suggesting crystallization from magma. They are markedly different from the zircons in the quartzite, with no smoothening of grain contours and medium grain in size (up to about $100 \mu \mathrm{m}$ or more). We consider that the magmatic zircons in the BIF were probably sourced from arc magmas, and were subsequently incorporated within oceanic sediments in subduction zone metamorphism. The weighted mean of ${ }^{206} \mathrm{~Pb} /{ }^{238} \mathrm{U}$ ages show $760 \pm 16 \mathrm{Ma}$ (error: $1 \sigma$ ) (Fig. 7), probably marking the timing of an active mid Neoproterozoic arc

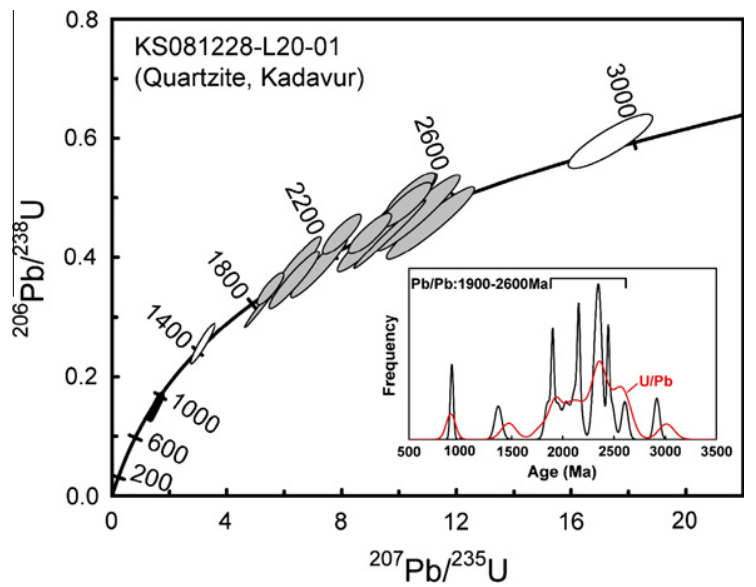

Fig. 6. Concordia diagram for quartzite (KS081228-L20-01) from Kadavur. Datapoint error ellipses in the concordia diagram are $2 \sigma$. As an exception, an ellipse of the youngest age of about $900 \mathrm{Ma}$ was drawn with exaggeration. The frequency diagram for ${ }^{207} \mathrm{~Pb} /{ }^{206} \mathrm{~Pb}$ ages is given with $2 \sigma$ error.

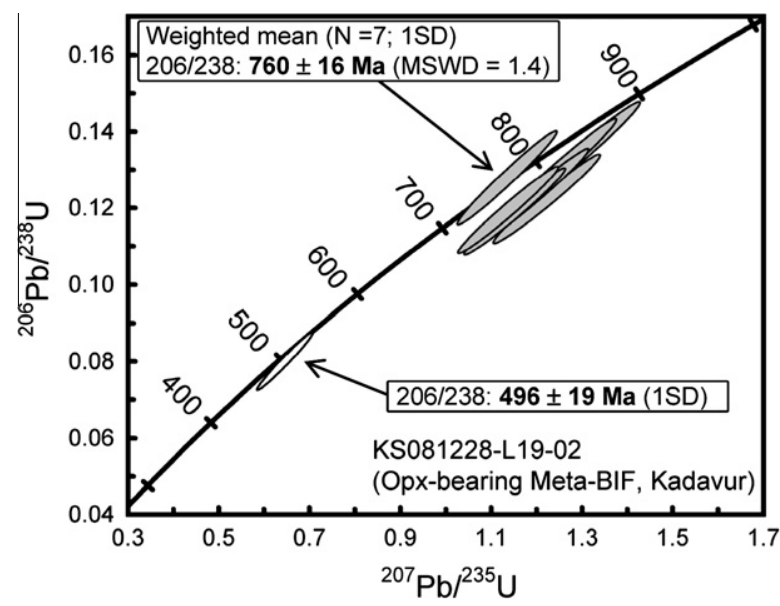

Fig. 7. Concodia diagram for orthopyroxene-bearing metamorphosed BIF (KS081228-L19-02) from Kadavur. Data-point error ellipses in the concordia diagram are $2 \sigma$. Weighted means were calculated from the data shown as filled ellipses.

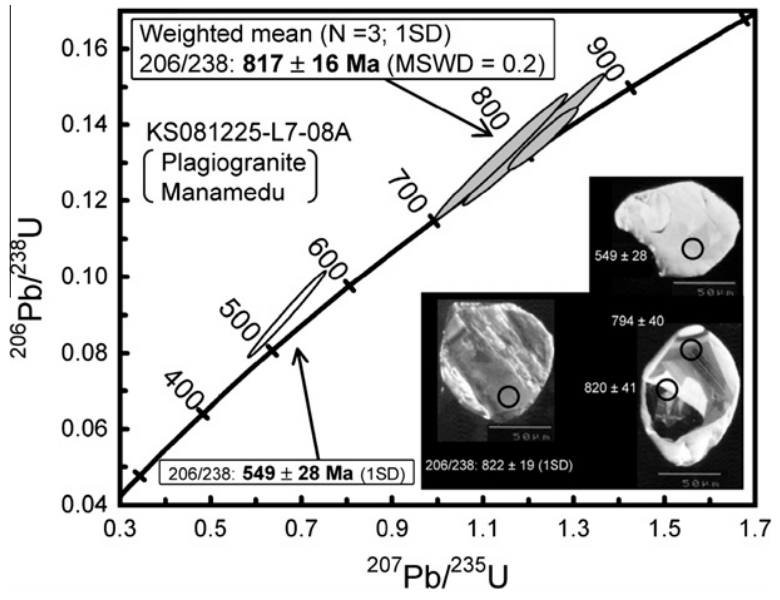

Fig. 8. Concodia diagram for plagiogranite (KS081225-L7-08A) from Manamedu, and $\mathrm{CL}$ images of zircons (with the ${ }^{206} \mathrm{~Pb} /{ }^{238} \mathrm{U}$ ages). Data-point error ellipses in the concordia diagram are $2 \sigma$. Weighted means were calculated from the data shown as filled ellipses. Spot size of each laser ablation in CL images: $16 \mu \mathrm{m}$.

associated with the subduction of the Mozambique Ocean slab. LA-ICP-MS spot analysis from the metamorphic overgrowth rim (Fig. 5b) of a zircon grain from the BIF shows yields Cambrian age (ca. $500 \mathrm{Ma}$; Fig. 7), which correlates with previous works for the timing of high-grade metamorphism in this region (e.g. Santosh et al., 2006; Collins et al., 2007a). The age is also in good agreement with the known timing for the final collision stage of the Gondwana supercontinent.

\subsection{Plagiogranite (Manamedu)}

Characteristically, zircons are extremely rare in plagiogranite, because of the low zirconium content in whole rock. But, even a few tiny grains would provide important information on the birth of the ocean floor. We could extract a few small grains of zircons (length up to $100 \mu \mathrm{m}$; Fig. 8) after crushing several tens of $\mathrm{kg}$ of the plagiogranite sample (KS081225-L7-08A). Among the zircons obtained, some show clear igneous texture in CL image. In this study, we selected those grains which do not contain mineral inclusions and cracks. The weighted mean of ${ }^{206} \mathrm{~Pb} /{ }^{238} \mathrm{U}$ ages yields an age of $817 \pm 16 \mathrm{Ma}$ (error: $1 \sigma$ ) (Fig. 8). An anhedral zircon from the plagiogranite yields ${ }^{206} \mathrm{~Pb} /{ }^{238} \mathrm{U}$ age of $549 \pm 28 \mathrm{Ma}$ (error: $1 \sigma$; Fig. 8 and Table 1), which corresponds well with the age obtained from the rim of the orthopyroxene-bearing metamorphosed BIF (KS081228-L19-02; Fig. 7). The age is also concordant with the published ages of high-grade metamorphism of the region (Santosh et al., 2006; Collins et al., 2007a).

\section{Discussion}

The preliminary zircon geochronological data presented in this study from a continental collision suture provides some clues on the tectonic history associated with ocean closure and the final amalgamation of the Late Neoproterzoic-Cambrian Gondwana supercontinent. Zircons from three samples were dated in this study: a plagiogranite from Manamedu hill associated with an imbricated ophiolite suite from within the suture zone, and quartzite and BIF from Kadavur farther south at the southern margin of the accretionary belt, at the northernmost domain of the Madurai Block. The older ages from detrital zircon cores obtained from the Kadavur quartzite sample (KS081228-L20-01) suggest an origin from Neoarchean-Paleoproterozoic sources, and the younger ages from these as well as the BIF (KS081228-L19-02) correlate to the 
timing of an active magmatic arc in mid Neoproterozoic, as well as the high-grade metamorphic event associated with the final collisional orogeny during the Late Neoproterozoic-Cambrian. The age data from the quartzite and metamorphosed BIF from Kadavur are compiled in Fig. 9. The Tera-Wasserburg concordia diagram shows a clear younger intercept age of $759 \pm 41 \mathrm{Ma}$ (error: $1 \sigma$ ). The age data obtained from the plagiogranite of Manamedu (KS081225-L7-08A; Fig. 8) might indicate the timing of the birth of the Mozambique Ocean floor to be around or prior to ca. $820 \mathrm{Ma}$ (Fig. 10a; see below). The younger intercept age of ca. $760 \mathrm{Ma}$ (Fig. 9) correlates with the age of the plagiogranite and might suggest the initiation of subduction and the birth of an arc (Fig. 10a). Isozaki (1997) defined the features of Ocean Plate Stratigraphy from the plate tectonic framework of southwestern Japan involving the concept of accretion of old ocean floor. Most of the lithologic association described in the present study corresponds well to an ancient Ocean Plate Stratigraphy with the various units metamorphosed during the latest NeoproterozoicCambrian. The presence of BIFs with accreted arkosic quartzite (at Kadavur) marks the arrival of the ocean plate at the trench (Fig. 10a). Alkaline magmatic plutons with ca. $750 \mathrm{Ma}$ ages also occur further north in Yelagiri and Sevattur (Miyazaki et al., 2000) and their relation to the plate tectonic framework of the PCSZ is presently unclear.

Santosh et al. (2009b) proposed a plate tectonic model for the subduction-accretion-collision history attending the various stages of the Wilson Cycle associated with the demise of the old Mozambique Ocean and the final amalgamation of the Gondwana supercontinent. Here, we re-intercept this model, based on the geochronological data obtained in this study (Fig. 10). The birth of the Mozambique Ocean floor might have occurred at or prior to ca. $820 \mathrm{Ma}$ (Fig. 10a), as indicated by the magmatic zircons from the plagiogranite (KS081225-L7-08A) which probably formed mid oceanic ridge basalt magma. The sequence of cumulate pyroxenite-gabbro-plagiogranite and metavolcanics at Manmedu in association with chert bands (Yellappa et al., 2010) suggests the traces of the subducted and accreted ocean floor. The quartzites in the Kadavur, further south of Manamedu represent arkosic sediments derived from a Neoarchean-Paleoproterozoic continental source and buried at the trench in the southward subducting Mozambique Ocean Plate between the Madurai Block (continental arc) in the south and the Dharwar Craton in the north (Vijaya Rao

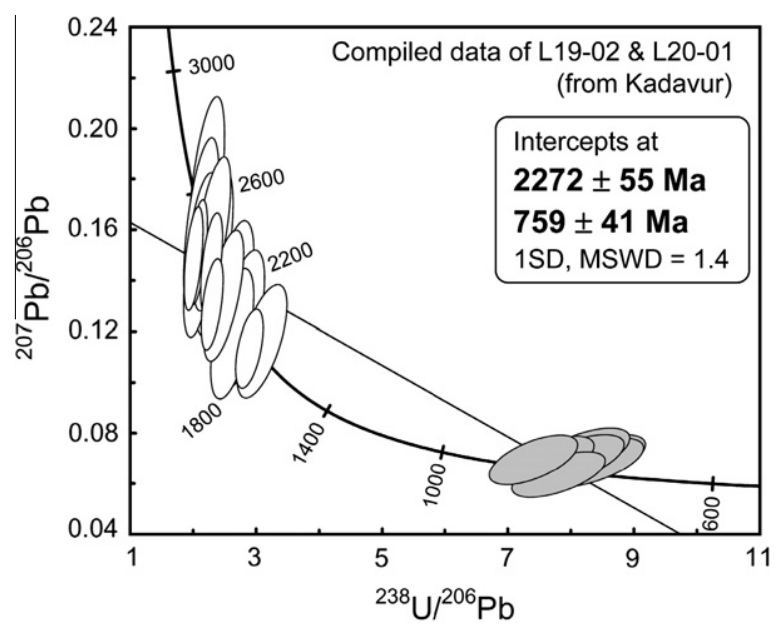

Fig. 9. Tera-Wasserburg concordia diagram for compiled data from quartzite and metamorphosed BIFs from Kadavur. Data-point error ellipses in the Concordia diagram are $2 \sigma$. Data sources: KS081228-L19-02 (Nos. 1-7; Table 1); KS081228L20-01 (Nos. 9-11, 13-21, 23-25). (a) 820 Ma or older

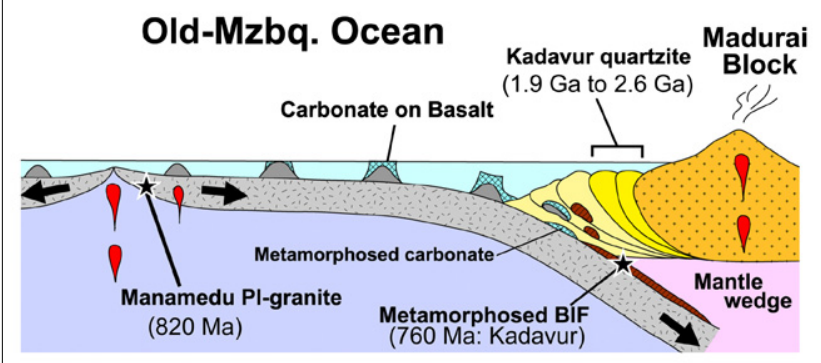

(b) $500 \mathrm{Ma}$ to $550 \mathrm{Ma}$

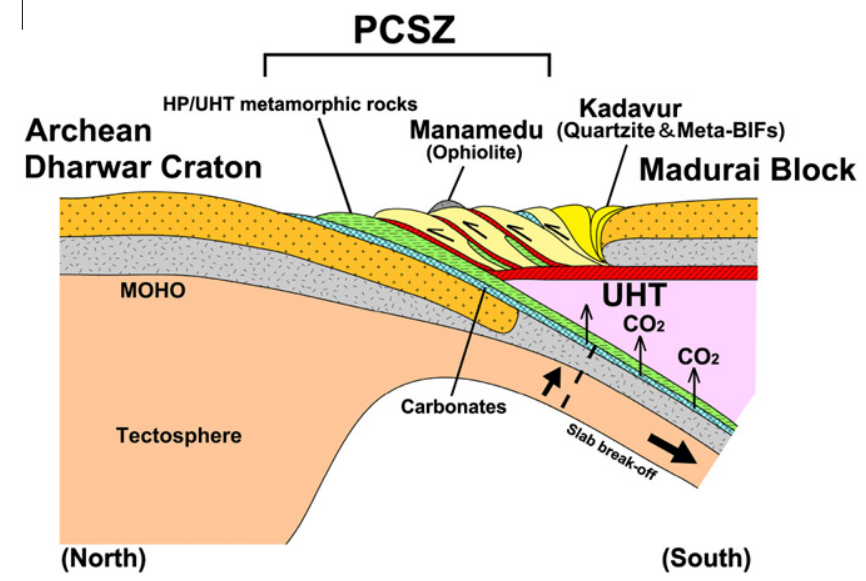

Fig. 10. Cartoon illustrations showing a tectonic model for the Gondwana suture along the Palghat-Cauvery Suture Zone (PCSZ) in southern India. (a) At about $820 \mathrm{Ma}$ or older (at the subduction-accretion stage). This illustration explains the timing of the opening of the Mozambique Ocean floor, which is correlated to magmatism for the plagiogranite formation. (b) At about 500-550 Ma (at the final stage of continent collision associated with Gondwana assembly).

et al., 2006; Santosh et al., 2009b; Naganjaneyulu and Santosh, 2010). The association of arkosic quartzite (KS081228-L20-01) with orthopyroxene-bearing metamorphosed BIF (KS081228-L1902 ) at Kadavur can be regarded as a metamorphosed accretionary sequence (Fig. 10a).

It is well known that most of the BIFs in the Earth were generated during a peak period of 1.9-3.8 Ga, especially in the time span of 1.9-2.7 Ga. For example, the Archean Dongwanzi ophiolite complex in the North China Craton formed at $2.5 \mathrm{Ga}$ includes BIFs (Kusky et al., 2001). On the other hand, some BIFs have been also reported as sediments which were deposited before or after the global Snowball Earth event at about $750 \mathrm{Ma}$ (e.g. Hoffman et al., 1998). Further detailed studies on the BIFs from Kadavur are required to evaluate their timing and role in the crustal evolutionary history of southern India.

The mid Neoproterozoic magmatic ages obtained from the plagiogranite within the PCSZ can be correlated with similar ages in Madagascar in the west and probably East Antarctica in the east within the Gondwana supercontinent ensemble (Sengupta et al., 1999; Collins et al., 2007a; Santosh et al., 2009b; Fig. 1). This age corresponds well to similar magmatic events reported in northern Madagascar (Collins, 2006) and/or the Sør Rondane Mountains in East Antarctica (Shiraishi et al., 2008) which all concentrate around 750-800 Ma. A long lived and extended Neoproterozoic arc seems to have been built through the continuous subduction of the Mozambique Ocean floor before the final collision and the incorporation of dispersed blocks within the Gondwana amalgam in the Cambrian. 


\section{Acknowledgements}

K. Sato thanks Dr. Y. Kon (AIST, Japan), Prof. E. Takahashi, Prof. S. Maruyama, Dr. S. Yamamoto, Dr. S. Omori, Dr. K. Aoki (Tokyo Inst. Tech.) for valuable discussions. Discussions with Dr. E.V.S.S.K. Babu and Mr. T. Yellappa (NGRI, India) during the fieldwork are also highly appreciated. Authors thank the staff at Gondwana Research Office in Trivandrum, Ms. Preetha Warrier, Mr. Syed Meha Fooz (Babu) and Mr. Mohan Doss for their helpful supports for this study. Constructive comments by Prof. Wenjiao Xiao, Prof. Santanu Kumar Bhowmik, and the Editor, Prof. Tim Kusky, are much appreciated. This study is a contribution to the 21 st Century COE Program "How to build habitable planets" (from July 2004 to March 2009) in the Tokyo Inst. Tech. that was sponsored by the Japan Ministry of Education, Culture, Sports, Science and Technology (MEXT) of the Japanese Government. The research was also supported by the Grant-in-aid for research project No. 21.5886 to K. Sato, No. 20340148 to T. Tsunogae, and No. 20340152 to T. Kawasaki (Ehime Univ., Japan) from the MEXT as well as INSA-JSPS joint research program (No. BDD20023).

\section{References}

Bartlett, J.M., Dougherty-Page, J.S., Harris, N.B.W., Hawkesworth, C.J., Santosh, M., 1998. The application of single zircon evaporation and model $\mathrm{Nd}$ ages to the interpretation of polymetamorphic terrains: an example from the Proterozoic mobile belt of south India. Contributions to Mineralogy and Petrology 131, 181195.

Bhaskar Rao, Y.J., Janardhan, A.S., Vijaya Kumar, T., Narayana, B.L., Dayal, A.M., Pantulu, G.V.C., Chetty, T.R.K., 2003. Sm-Nd model ages and Rb-Sr isotopic systematics of charnockite gneisses across the Cauvery Shear Zone, southern India. In: Ramakrishnan, M. (Ed.), Implications to the Archean-Neoproterozoic Terrane Boundary in the Southern Granulite Terrain, vol. 50. Geological Society of India Memoir, pp. 297-317.

Brown, M., Raith, M., 1996. First evidence of ultrahigh-temperature decompression from the granulite province of southern India. Journal of Geological Society London 153, 819-822.

Chetty, T.R.K., Bhaskar Rao, Y.J., 2006a. The Cauvery Shear Zone, Southern Granulite Terrain, India: a crustal-scale flower structure. Gondwana Research 10, 7785.

Chetty, T.R.K., Bhaskar Rao, Y.J., 2006b. Constrictive deformation in transpressional regime: field evidence from the Cauvery Shear Zone, Southern Granulite Terrain, India. Journal of Structural Geology 28, 713-720.

Clark, C., Collins, A.S., Timms, N.E., Kinny, P.D., Chetty, T.R.K., Santosh, M., 2009. SHRIMP U-Pb age constraints on magmatism and high-grade metamorphism in the Salem Block, southern India. Gondwana Research 16, 27-36.

Collins, A.S., 2006. Madagascar and the amalgamation of Central Gondwana. Gondwana Research 9, 3-16.

Collins, A.S., Pisarevsky, S.A., 2005. Amalgamating eastern Gondwana: the evolution of the Circum-Indian Orogens. Earth-Science Review 71, 229-270.

Collins, A.S., Clark, C., Sajeev, K., Santosh, M., Kelsey, D.E., Hand, M., 2007a. Passage through India: the Mozambique Ocean suture, high-pressure granulites and the Palghat-Cauvery shear zone. Terra Nova 19, 141-147.

Collins, A.S., Santosh, M., Braun, I., Clark, C., 2007b. Age and sedimentary provenance of the Southern Granulites, South India: U-Th-Pb SHRIMP secondary ion mass spectrometry. Precambrian Research 155, 125-138.

Eggins, S.M., Kinsley, L.P.J., Shelley, J.M.G., 1998. Deposition and element fractionation processes during atmospheric pressure laser sampling for analysis by ICP-MS. Applied Surface Science 127-129, 278-286.

Geological Survey of India, 1995. Geological and Mineral Map of Tamil Nadu and Pondicherry.

Harris, N.B.W., Santosh, M., Taylor, P.N., 1994. Crustal evolution in south India: constrains from Nd isotopes. Journal of Geology 102, 139-150.

Hirata, T., Nesbitt, R.W., 1995. U-Pb isotope geochronology of zircon: evaluation of the laser probe-inductively coupled plasma mass spectrometry technique. Geochimica et Cosmochimica Acta 59, 2491-2500.

Hirata, T., Iizuka, T., Orihashi, Y., 2005. Reduction of mercury background on ICPmass spectrometry for in-situ U-Pb age determinations of zircon samples. Journal of Analytical Atomic Spectrometry 20, 696-701.

Hoffman, P.F., Kaufman, A.J., Halverson, G.P., Schrag, D.P., 1998. A Neoproterozoic Snowball Earth. Science 281, 1342-1346

Hussain, S.M., Narayana, B.L., Naqvi, S.M., 1996. Plagiogranite differentiates from ultramafic-mafic-felsic suite along Cauvery Suture at Manamedu in the granite terrain of South India. In: Proceedings of the 9th Convention of Indian Geological Congress, pp. 155-160.

Iizuka, T., Hirata, T., 2004. Simultaneous determinations of U-Pb age and REE abundances for zircons using ArF excimer laser ablation-ICPMS. Geochemical Journal 38, 229-241.
Ishii, S., Tsunogae, T., Santosh, M., 2006. Ultrahigh-temperature metamorphism in the Achankovil Zone: implications for the correlation of crustal blocks in southern India. Gondwana Research 10, 99-114.

Isozaki, Y., 1997. Jurassic accretion tectonics of Japan. The Island Arc 6, 25-51.

Kanazawa, T., Tsunogae, T., Sato, K., Santosh, M., 2009. The stability and origin of sodicgedrite in ultrahigh-temperature Mg-Al granulites: a case study from the Gondwana suture in southern India. Contributions to Mineralogy and Petrology $157,95-110$.

Katayama, I., Maruyama, S., Parkinson, C.D., Terada, K., Sano, Y., 2001. Ion microprobe $\mathrm{U}-\mathrm{Pb}$ zircon geochronology of peak and retrograde stages of ultrahighpressure metamorphic rocks from the Kokchetav massif, northern Kazakhstan. Earth and Planetary Science Letters 188, 185-198.

Koshimoto, S., Tsunogae, T., Santosh, M., 2004. Sapphirine and corundum bearing ultrahigh temperature rocks from the Palghat-Cauvery Shear System, southern India. Journal of Mineralogical and Petrological Sciences 99, 298-310.

Kretz, R., 1983. Symbols for rock-forming minerals. American Mineralogist 68, 277 279.

Kusky, T.M., Li, J.H., Tucker, R.D., 2001. The Archean Dongwanzi ophiolite complex, North China Craton: 2.505-billion-year-old oceanic crust and mantle. Science 292, 1142-1145.

Ludwig, K.R., 2003. User's Manual for Isoplot 3.00. A Geochronological Toolkit for Microsoft Excel. Berkelry Geochronology, Center Special Publication 4, pp. 1-70.

Meert, J.G., Lieberman, B.S., 2008. The Neoproterozoic assembly of Gondwana and its relationship to the Ediacaran-Cambrian radiation. Gondwana Research 14, $5-21$.

Miller, J.S., Santosh, M., Pressley, R.A., Clements, A.S., Rogers, J.J.W., 1996. A PanAfrican thermal event in southern India. Journal of Southwest Asian Earth Sciences 14, 127-136.

Miyazaki, T., Kagami, H., Shuto, K., Morikiyo, T., Ram Mohan, V., Rajasekaran, K.C., 2000. Rb-Sr geochronology, $\mathrm{Nd}-\mathrm{Sr}$ isotopes and whole rock geochemistry of Yelagiri and Sevattur syenites, Tamil Nadu, South India. Gondwana Research 3. 39-53.

Morimoto, T., Santosh, M., Tsunogae, T., Yoshimura, Y., 2004. Spinel + quartz association from the Kerala khondalites, southern India: evidence for ultrahightemperature metamorphism. Journal of Mineralogical and Petrological Sciences 99, 257-278

Naganjaneyulu, K., Santosh, M., 2010. The Cambrian collisional suture of Gondwana in southern India: a geophysical appraisal. Journal of Geodynamics 50, 256-267.

Nishimiya, Y., Tsunogae, T., Santosh, M., 2008. Petrology and fluid inclusions of garnet-clinopyroxene rocks from Paramati in the Palghat-Cauvery Shear Zone System, southern India. Journal of Mineralogical and Petrological Sciences 103, 354-360.

Nishimiya, Y., Tsunogae, T., Santosh, M., 2010. Sapphirine + quartz corona around magnesian $\left(X_{\mathrm{Mg}} \sim 0.58\right)$ staurolite from the Palghat-Cauvery Suture Zone, southern India: evidence for high-pressure and ultrahigh-temperature metamorphism within the Gondwana suture. Lithos 114, 490-502.

Ohyama, H., Tsunogae, T., Santosh, M., 2008. Carbonic fluid inclusions in ultrahightemperature granulite from Kumiloothu in the northern Madurai Block, southern India. Journal of Mineralogical and Petrological Sciences 103, 273-278.

Raharimahefa, T., Kusky, T., 2006. Structural and remote sensing studies of the southern Betsimisaraka Suture, Madagascar. Gondwana Research 10, 186-197.

Raharimahefa, T., Kusky, T., 2009. Structural and remote sensing analysis of the Betsimisaraka Suture in northeastern Madagascar. Gondwana Research 15, 14 27.

Raharimahefa, T., Kusky, T., 2010. Temporal evolution of the Angavo and related shear zones in Gondwana: constraints from LA-MC-ICP-MSU-Pb zircon ages of granitoids and gneiss from central Madagascar. Precambrian Research 182, 30 42.

Sajeev, K., Osanai, Y., Santosh, M., 2004. Ultrahigh-temperature metamorphism followed by two-stage decompression of garnet-orthopyroxene-sillimanite granulites from Ganguvarpatti, Madurai block, southern India. Contributions to Mineralogy and Petrology 148, 29-46.

Santosh, M., Kusky, T., 2010. Origin of paired high pressure-ultrahigh-temperature orogens: a ridge subduction and slab window model. Terra Nova 22, 35-42.

Santosh, M., Omori, S., 2008. $\mathrm{CO}_{2}$ flushing: a plate tectonic perspective. Gondwana Research 13, 86-102.

Santosh, M., Sajeev, K., 2006. Anticlockwise evolution of ultrahigh-temperature granulites within continental collision zone in southern India. Lithos 92, 447464.

Santosh, M., Yokoyama, K., Biju-Sekhar, S., Rogers, J.J.W., 2003. Multiple tectonothermal events in the granulite blocks of southern India revealed from EPMA dating: implications on the history of supercontinents. Gondwana Research 6, 29-63.

Santosh, M., Tsunogae, T., Koshimoto, S., 2004. First report of sapphirine-bearing rocks from the Palghat-Cauvery Shear Zone system, southern India. Gondwana Research 7, 620-626.

Santosh, M., Collins, A.S., Tamashiro, I., Koshimoto, S., Tsutsumi, Y., Yokoyama, K. 2006. The timing of ultrahigh-temperature metamorphism in southern India: $\mathrm{U}-\mathrm{Th}-\mathrm{Pb}$ electron microprobe ages from zircon and monazite in sapphirinebearing granulites. Gondwana Research 10, 128-155.

Santosh, M., Maruyama, S., Yamamoto, S., 2009a. The making and breaking of supercontinents: some speculations based on superplumes, super downwelling and the role of tectosphere. Gondwana Research 15, 324-341.

Santosh, M., Maruyama, S., Sato, K., 2009b. Anatomy of a Cambrian sture in Gondwana: Pacific-type orogeny in southern India? Gondwana Research 16 321-341. 
Santosh, M., Tsunogae, T., Shimizu, H., Dubessy, J., 2010. Fluid characteristics of retrogressed eclogites and mafic granulites from the Cambrian Gondwana suture in southern India. Contributions to Mineralogy and Petrology 159, 349-369.

Sato, K., Santosh, M., Tsunogae, T., 2009. A petrologic and laser Raman spectroscopic study of sapphirine-spinel-quartz-Mg-staurolite inclusions in garnet from Kumiloothu, southern India: implications for extreme metamorphism in collisional orogen. Journal of Geodynamics 47, 107-118.

Sato, K., Santosh, M., Tsunogae, T., Kon, Y., Yamamoto, S., Hirata, T., 2010a. Lase ablation ICP mass spectrometry for zircon $\mathrm{U}-\mathrm{Pb}$ geochronology of ultrahightemperature gneisses and A-type granites from the Achankovil Suture Zone, southern India. Journal of Geodynamics 50, 286-299.

Sato, K., Santosh, M., Tsunogae, T., 2010b. High $P-T$ phase relation of magnesian $\left(\mathrm{Mg}_{0.7} \mathrm{Fe}_{0.3}\right)$ staurolite composition in the system $\mathrm{FeO}-\mathrm{MgO}-\mathrm{Al}_{2} \mathrm{O}_{3}-\mathrm{SiO}_{2}-\mathrm{H}_{2} \mathrm{O}$ : implications for prograde high-pressure history of ultrahigh-temperature metamorphic rocks. American Mineralogist 95, 177-184.

Sato, K., Santosh, M., Tsunogae, T., Chetty, T.R.K., Hirata, T., in press. Laser ablation ICP mass spectrometry for zircon U-Pb geochronology of metamorphosed granite from the Salem Block: Implication for Neoarchean crustal evolution in southern India. Journal of Mineralogical and Petrological Sciences. doi:10.265/ jmps.091222.

Sengupta, P., Sen, J., Dasgupta, S., Raith, M., Bhui, U.K., Ehl, J., 1999. Ultra-high temperature metamorphism of metapelitic granulites from Kondapalle, Eastern Ghats Belt: implications for the Indo-Antarctic correlation. Journal of Petrology 40, 1065-1087.

Shimpo, M., Tsunogae, T., Santosh, M., 2006. First report of garnet-corundum rocks from southern India: implications for prograde high-pressure (eclogite-facies?) metamorphism. Earth and Planetary Science Letters 242, 111-129.

Shiraishi, K., Dunkley, D.J., Hokada, T., Fanning, C.M., Kagami, H., Hamamoto, T. 2008. Geochronological constraints on the Late Proterozoic to Cambrian crustal evolution of eastern Dronning Maud Land, East Antarctica: a synthesis of SHRIMP U-Pb age and Nd model age data. In: Satish-Kumar, M., Motoyoshi, Y. Osanai, Y., Hiroi, Y., Shiraishi, K. (Eds.), Geodynamic Evolution of East Antarctica: A Key to the East-West Gondwana Connection, vol. 308. Geological Society, Special publication, London, pp. 21-67.

Stacey, J.S., Kramers, J.D., 1975. Approximation of terrestrial lead isotope evolution by a two-stage model. Earth and Planetary Science Letters 26, 207-221.

Tadokoro, H., Tsunogae, T., Santosh, M., Yoshimura, Y., 2007. First report of the spinel + quartz assemblage from Kodaikanal in the Madurai Block, southern India: implications for ultrahigh-temperature metamorphism. International Geology Review 49, 1050-1068.
Tadokoro, H., Tsunogae, T., Santosh, M., 2008. Metamorphic $P-T$ path of the eastern Trivandrum Granulite Block, southern India: implications for regional correlation of lower crustal fragments. Journal of Mineralogical and Petrological Sciences 103, 279-284.

Tateishi, K., Tsunogae, T., Santosh, M., Janardhan, A.S., 2004. First report of sapphirine + quartz assemblage from southern India: implications for ultrahigh-temperature metamorphism. Gondwana Research 7, 899-912.

Tsunogae, T., Santosh, M., 2003. Sapphirine and corundum-bearing granulites from Karur, Madurai Block, southern India. Gondwana Research 6, 925-930.

Tsunogae, T., Santosh, M., 2006. Reply to comment on "first report of garnetcorundum rocks from southern India: implications for prograde high-pressure (eclogite-facies?) metamorphism". In: Kelsey, D.E., Clark, C., Hand, M., Collins, A.S. (Eds.), Earth and Planetary Science Letters, vol. 249, pp. 535-540.

Tsunogae, T., Santosh, M., 2010. Ultrahigh-temperature metamorphism and decompression history of sapphirine granulites from Rajapalaiyam, southern India: implications for the formation of hot orogens during Gondwana assembly. Geological Magazine 147, 42-58.

Tsunogae, T., Santosh, M., Shimpo, M., 2007. Sodicgedrite in ultrahigh-temperature $\mathrm{Mg}$-Al-rich rocks from the Palghat-Cauvery Shear Zone system, southern India. Journal of Mineralogical and Petrological Sciences 102, 39-43.

Tsunogae, T., Santosh, M., Ohyama, H., Sato, K., 2008a. High-pressure and ultrahightemperature metamorphism at Komateri, northern Madurai Block, southern India. Journal of Asian Earth Sciences 33, 395-413.

Tsunogae, T., Santosh, M., Dubessy, J., 2008b. Fluid characteristics of high- to ultrahigh-temperature metamorphism in southern India: a quantitative Raman spectroscopic study. Precambrian Research 162, 198-211.

Vijaya Rao, V., Sain, K., Reddy, P.R., Mooney, W.D., 2006. Crustal structure and tectonics of the northern part of the Southern Granulite Terrane, India. Earth and Planetary Science Letters 251, 90-103.

Walder, A.J., Abell, I.D., Platzner, I., Freedman, P.A., 1993. Lead isotope ratio measurement of NIST 610 glass by laser ablation inductively coupled plasma mass spectrometry. Specrochimica Acta Part B: Atomic spectroscopy 48, 397402 .

Wiedenbeck, M., Alle, P., Corfu, F., Griffin, W.L., Meier, M., Oberli, F., Von Quadt, A., Roddick, J.C., Spiegel, W., 1995. Three natural zircon standards for U-Th-Pb, LuHf, trace element and REE analyses. Geostandards Newsletter 19, 1-23.

Yellappa, T., Chetty, T.R.K., Tsunogae, T., Santosh, M., 2010. The Manamedu complex: geochemical constraints on Neoproterozoic suprasubduction zone ophiolite formation within the Gondwana suture in southern India. Journal of Geodynamics 50, 268-285. 